\title{
Orta Yetişkinlik Dönemindeki Geylerde Mutluluk Söylemi Olarak "Uzun Süreli ve Güvenli Partner İlişkisi”
}

\author{
“Long-Term and Safe Partner Relationship” as a Happiness Discourse of Middle Aged Gay Men
}

\section{Dilek ÖZKAN ${ }^{11]}$ Umut ŞAH[2]}

Başvuru Tarihi:4 Nisan 2021

Türkiye'de bugüne kadar geylerin mutluluklarını üzerine inşa ettikleri söylemlere veya söylemsel kaynaklara dair bir çalışma yapılmamıştır. Özkan'ın (2019) yüksek lisans tezi kapsamında gerçekleștirdiği araştırma sonucunda İstanbul'da yaşayan orta yetişkinlik dönemindeki geylerin mutluluğa dair konuşmalarına kaynaklık eden 7 açıklayıcı repertuar tespit edilmiştir. Bu makalede ise Özkan'ın çalışmasında ulaşılan açıklayıcı repertuarlardan biri olan "Uzun Süreli/Güvenli Partner İlişkisi" repertuarı detaylı bir şekilde analiz edilmektedir. Makaleye temel oluşturan araștırmada, İstanbul'da yaşayan 45-62 yaş arasında, farklı eğitim, gelir ve meslek gruplarından 10 gey ile yarı-yapılandırılmıș derinlemesine bireysel görüşmeler yapılmıștır. Ses kayıt cihazıyla kaydedilen görüşmeler yazıya aktarılmış ve metinler söylem analizi yöntemi ile incelenmiștir. Araștırma kapsamında, hazırlık amacıyla öncelikle bir pilot görüşme gerçekleștirilmiştir ve görüşmede "öznel iyi oluş" kavramının psikoloji alanı profesyoneli olmayan kişilere uzak gelmesi nedeniyle soru formunda bu kavram, "mutluluk" ve "yaşam doyumu" ile ikame edilmiştir. Görüșmelerde öznel iyi oluşun parametreleri olan ilişkiler, kişilik yapısı, inanç, eğitim seviyesi, gelir düzeyi ve sağlı̆ın mutlu ve doyumlu yaşama sahip hissetmeleriyle ilişkisi sorulmuştur. Katılımcıların öznel olarak kendilerini iyi ve mutlu olarak tanımlamalarında bir yandan uzun süreli/güvenli bir partner ilişkisinin varlığını öne çıkardıkları, diğer yandan gerek yaşlandıkça beğenilmeyecek olmaları gerekse gey camiada güvenli/uzun süreli ilişkilerin pek mümkün olmaması itibariyle de ilişki olasılıklarını düşük gördükleri tespit edilmiştir. Gey camiada geçmişe göre sadakatin azaldığı ve hatta artık olmadığına dair sıkça ifade edilen görüş, güvenli bir ilişki yaşamanın önünde duran ve kabullenilmiş bir "gerçeklik" olarak inşa edilmiştir. Görüşülen katılımcılar, sadakatin artık olmadığını ifade ettikleri gey cemaatten bireyler olarak hem bundan şikâyet edip bunun karşısında kendilerini edilgen konumluyor hem de bunu normal kabul ediyor görünmektedirler.

Anahtar Kelimeler: gey, orta yetişkinlik, öznel iyi oluş, güvenli ilişki, söylem analizi

Received Date:4 April 2021

Accepted Date:22 June 2021

So far, there has been no study of the discourses that gay people build on their happiness in Turkey. As a result of the Özkan's (2019) research as her master theis, 7 interpretative repertoires have been identified that refer to the conversations of gays in middle adulthood living in Istanbul about happiness. In this article, the repertoire of "long term/secure partner relationship", which is one of the explanatory repertoires reached in Özkan's work, is analyzed in detail. Within the scope of the research, which formed the basis for the article, semi-structured in-depth individual interviews were conducted with 10 gays from different education, income and professional groups between the ages of 45 and 62 living in Istanbul. The interviews recorded with the voice recorder were transcribed into writing and the texts were examined by the method of discourse analysis. In interviews, relationships, personality structure, belief, education level, income level and health were asked about their relationship with the feeling of having a happy and satisfied life. It was determined that the participants of the study subjectively considered themselves to be good and happy, on the one hand, suggesting the existence of a long-term/safe partner relationship, on the other hand, they would not be liked as they got older, and they considered their relationship probability low due to the fact that safe/long-term relationships. In gay community, the often expressed view that loyalty has diminished and even no longer exists is constructed as an accepted "reality" that stands in the way of having a safe relationship. The interviewees, as individuals from the gay community where they express no more loyalty, both complain about it and position themselves passive in the face of it and seem to accept it as normal.

Keywords: gays, middle adulthood, subjective well-being, safe relationships, discourse analysis ilişkisi”. Humanistic Perspective, 3 (2), 531-556. https://doi.org/10.47793/hp.909401

* Bu çalıșma birinci yazarın ikinci yazar danıșmanlığında yürüttüğü yüksek lisans tez çalıșmasından üretilmiștir.

This study was produced from the master thesis study conducted by the first author under the supervision of the second author.

[1] Doktora | Üsküdar Üniversitesi | Fen Edebiyat Fakültesi | Psikoloji | İstanbul | Türkiye | ORCID: 0000-0002-3502-6417| dilekozkan@outlook.com [2] Öğr. Gör. | Işıı Üniversitesi | Fen Edebiyat Fakültesi | Psikoloji | İstanbul | Türkiye | ORCID: 0000-0002-5376-0965

Humanistic Perspective - 2021, Cilt 3, Sayı 2, Sayfa 531-556 


\section{GíRiş}

$\mathrm{P}$

sikolojinin ana inceleme alanları arasında olan mutluluk ve bireyin iyi oluşuna dair ilgi, Antik Yunan filozoflarının "insan nasıl mutlu olur" sorusuna ve çok daha öncesine kadar dayanmaktadır. Öznel iyi oluşun belirleyicileri üzerine yapılan çalışmalar son yirmi yılda önemli bilgiler üretmiş olmakla birlikte, heteronormatif yaklaşıma bağlı olarak bu çalışmaların çoğunlukla heteroseksüel erkek ve kadın katılımcılarla yürütüldükleri görülmektedir. Büyük toplulukların, çeşitlilik içeren alt gruplardan oluştuğu göz önünde bulundurularak, bu çeşitliliğin öznel iyi oluş üzerinde de farklı etkileri olacağı unutulmamalıdır.

Bu çalışmada, mutluluğu da kapsayan çatı bir kavram olan öznel iyi oluşa dair orta yetişkinlik dönemindeki geylerin söylemleri ele alınmaktadır. Bu amaçla, çalışma kapsamında, İstanbul'da yaşayan orta yetişkinlik dönemindeki geylerin öznel iyi oluşlarına dair açılamalarında öne çıkan söylemsel kaynakların (repertuarların) neler olduğu anlaşılmaya çalışılmıştır. Bu kısımda, öncelikle, çalışmanın kavramsal çerçevesini oluşturan kavramlar sunulmaktadır.

\section{Öznel İyi Oluş}

Psikoloji açısından her zaman öncelikli bir araştırma konusu olan öznel iyi oluş kavramını Diener (1984) "bireylerin yüksek yaşam doyumları, sık olumlu duyguları ve daha az seviyede olumsuz duyguları yaşaması" olarak tanımlamış, ayrıca öznel iyi oluşun olumlu duygulanım, olumsuz duygulanım ve yaşam doyumu olmak üzere öne çıkan üç öğesi olduğunu belirtmiştir. Bu kavramların ölçülebilir olması için Diener ve arkadaşları (1985) Yaşam Doyumu Ölçeği'ni geliştirmişlerdir.

Mutluluğun bireyi olumlu yönde etkilediği konusunda görüş birliği bulunmakla birlikte bireylerin nasıl mutlu oldukları konusunda farklı yaklaşımlar bulunmaktadır. Ryff (1995) mutluluğu belirleyen 6 boyut tanımlamıştır; özerklik, çevre ile ilişkilerde hâkimiyet kurma, kişisel gelişim, diğerleriyle olumlu ilişkiler kurma, otonomi, yaşam amacı ve kendini kabul etme. Ayrıca Ryff'e (1995) göre bir kişinin iyi olduğunu söyleyebilmesi için kaygı bozukluğu, depresyon ve diğer psikolojik rahatsızlıklara sahip olmaması gerekir.

Diener ve Ryan (2009) ise öznel iyi oluşu, bireylerin kendi yaşamlarını öznel değerlendirmelerine göre tecrübe ettikleri iyi oluş düzeyini tanımlayan çatı kavram olarak nitelemektedirler. Bu çatı kavramın altında yaşam doyumu, yaşam olaylarına duyulan sevinç ya da üzüntü, iș, ilişkiler, sağlık, eğlence, anlam ve amaç gibi alanlara dair bilişsel ve duygusal tepkiler bulunmaktadır.

Çeşitli araştırmalar, öznel iyi oluşu etkileyen üç değişken grubu tanımlamaktadır; demografik faktörler, amaçlı etkinlikler ve genetik yatkınlık (Lyubomirsky, Sheldon ve Schade, 
2005; Myers ve Diener, 1995). Yaş, cinsiyet, eğitim ve gelir gibi değişkenler "demografik" faktörleri; bedensel istekleri doyurmak, insanlarla etkileşime geçmek, dini inancın gereğini yerine getirmek gibi etkinlikler "amaçlı" etkinliklerin içeriğini; duygusal denge, sorumluluk, deneyime açıklık, dışadönüklük gibi kişilik özellikleri de "genetik yatkınlığın” içeriğini oluşturmaktadır. Genetik yatkınlığın öznel iyi oluş üzerinde yüzde elli düzeyinde belirleyici etkisi olduğundan söz edilmektedir (Kagan, 2003).

Öznel iyi oluş düzeyi ile ilişkili kavramlar içerisinde sosyal ilişkiler, iş ve gelir, sağlık ve yaşam süresi, cinsiyet, eğitim, yaş, din ve kültür öne çıkmaktadır (Diener ve Ryan, 2009). Sosyal desteğin sağlandığı ilişkiler içinde yer almanın kişinin olumlu duygular yaşamasını sağlayacağına, sosyal desteğin stresten koruyucu olduğuna ve iyi oluş seviyesine olumlu katkı yapacağına dikkat çekilmektedir (Yalçın, 2014). Bunun yanı sıra sosyal üretkenliğin de psikolojik iyi oluş hâlini yordadığı belirtilmektedir (Yüksel ve ark., 2015). Ayrıca hastalık, ayrılık, işsizlik ve sosyal destek ağının olmaması halleriyle öznel iyi oluşun da düşük olması arasında yüksek oranda bağlantı bulunmaktadır (Dolan ve ark., 2008).

Keyes ve Ryff'in (1999) kültürler arası farkı da öncelemek için ABD ve Güney Kore'de orta yetişkinlik dönemindeki bireylerle yaptıkları araştırma sonucuna göre iki kültürde de öznel iyi oluş aile ve evlilik ilişkisi üzerinden ağırlıklı olarak değerlendirilmektedir. Owen ve arkadaşlarının (2017) Türkiye'de yaptıkları 314 kişi üzerindeki iyilik hali araştırmasında cinsiyet ve yaş grupları arasında iyilik hali puanları açısından anlamlı fark bulunmamıştır. Ortalamalarda romantik ilişkisi olan ve ilişkisinden memnuniyeti artanların toplam iyilik hali puanlarında da anlamlı yükseliş tespit edilmiştir.

Kasapoğlu ve Kış'ın (2016) yaptıkları meta analiz çalışmasında 10 sene içinde yapılan 101 öznel iyi oluş araştırmasında heteronormatif bakış açısıyla kadın ve erkek cinsiyetleri arasında anlamlı bir fark olup olmadı̆̆ı incelenmiş ve kadınlar lehine önemsiz düzeyde bir fark bulunduğu ortaya konulmuştur.

\section{Orta Yetişkinlik}

İnsan yaşamında öznel iyi oluş incelenirken, farklı gelişim dönemlerinde öznel iyi oluşu etkileyen faktörlerde değişiklikler olduğu görülmektedir. Genel olarak 45 ile 65 yaş arası olarak kabul edilen orta yetişkinlik dönemi, birçok kişi için büyüme ve kaybın dengelendiği bir dönem olarak öne çıkmaktadır (Erikson, 1997). Orta yetişkinlik, çeşitli fizyolojik ve bilişsel değişimlerle birlikte yaklaşmakta olan yaşlılık dönemine hazırlık, geride bırakılan yaşamın değerlendirmesi ve özellikle yeni nesillere deneyim aktarımının en yoğun gözlendiği yaş aralığıdır.

Erikson'ın (1997) kuramına göre 45-65 yaş arasındaki orta yetişkinlik dönemi, en uzun yaşam dönemi ve "üretkenliğe karşı durgunluk" karşıtlığının yaşandığı dönem olarak 
tanımlanmaktadır. Üretkenlik; üreme, verimlilik ve yaratıcılığı, dolayısıyla da yeni nesiller, yeni ürünler ve fikirler üretmeyi kapsar (Erikson, 1997), aynı zamanda üretken çabalar aracılığıyla "yeni nesli oluşturma ve rehberlik etme ilgisini" de içerir (Miller, 2017). "Üretkenliğe karşı durgunluk" evresinin toplumun kuşaktan kuşağa sürdürülmesini sağlayan mekanizma olduğu ifade edilmektedir (Miller, 2017). Buna karşılık bir durağanlık algısı da mevcuttur ve özellikle üretkenlikle ilgili süreçlere artık aktif olarak katılmayanları ele geçirebilir. Erikson'a göre üretkenlik "içtenlikli ilgi" ile kişinin başkalarını önemsemesi, insanlar ve fikirlerle ilgilenmesi ve onlara özen göstermesi yükümlülügünü de ifade eder. İş ve aile ilişkileri kişiyi başkalarıyla ilgilenme sorumluluğuyla baş başa bırakır. Kişinin ilgilenmesi gereken şeylerle birlikte katılması gereken kutlamalar da artmıştır ve bunlar doyurucu bütünlük taşırsa bu dönemde her şey yolunda gider (Erikson, 1997).

Orta yetişkinlik dönemi insan hayatının oldukça büyük bir bölümünü kapsamaktadır ve Avrupa ile ABD'de oran olarak nüfus içindeki en geniş grup olmaya başlamasıyla bu alandaki araştırmalar da çoğalmaya başlamıştır. Orta yaş dönemine dair araştırmalar incelendiğinde bu dönemin kazançlarla kayıplar arasındaki dönüm noktası olduğu belirtilmekte, geriye kalan yaşam süresinin azalmasıyla birlikte hayatı sorgulama, iş ve aile yaşamını gözden geçirme, değerlendirme süreci olarak ele alınmaktadır (Lachman, 2004). Specht (2017) orta yetişkinlik dönemini duygusal istikrarın artmaya devam ettiği bir dönem olarak tanımlamış; Levinson (1986) ise orta yetişkinlik döneminde erkeklerin "şimdi elimde ne var" ve "gerçekten isteğim ne" gibi soruların peşinde olduklarını ifade etmiștir.

Öznel iyi oluş ile yaş arasında bazı araştırmalarda anlamlı ilişkiler bulunmuş, bazı çalışmalarda ise öznel iyi oluşun yaşla birlikte arttığı görülmüş, belli bir yaştan sonra düşmediği sonucuna varılmıştır (Ryff, 1989). Spiro ve Mrozeck'in araștırmasına (2005) göre de yaşam memnuniyeti 40-65 yaşları arasında yükselmekte fakat ölümün yaklaşmasının hissedildiği ileri yaşlarda azalmaktadır. Bunun yanı sıra ABD'lilerle yapılan bir araştırmada öznel iyi oluşu etkileyen en önemli öğelerden yaşam doyumunun yaşam boyu incelendiğinde " $U$ " şekli çizdiği, genç yetişkinlikte ve yaşlılık döneminde daha yüksekken orta yetişkinlikte özellikle 50 yaş civarında en düşük seviyede olduğu da belirtilmiştir (Luhmann, 2017). Diener ve Ryan'a (2009) göre yaş ve öznel iyi oluş arasında uluslararası çapta inceleme yapıldığında tutarlı bir ilişki bulunmamaktadır. Bu araştırmalarda eşcinsel bireyler dahil edilmemiştir.

\section{Eşcinsellik ve Öznel İyi Oluş}

"Eşcinsellik" kelimesi, eski Yunan'da "benzer" anlamındaki "amos" ve "cinsellik" anlamındaki "sexuality" kelimelerinin birleșmesinden bir araya gelen "homosexuality" kelimesinin Türkçe karşılığı olarak kullanılmaktadır (Güney, Kargı ve Çorbacı-Oruç, 2004). Tüm canlılarda olduğu gibi insanlar arasında da görülen cinsel yönelimlerden biri olan eșcinsellik, 
kişinin kendisiyle aynı atanmış cinsiyetten olan kişilere yönelik cinsel/romantik çekim hissetmesi anlamına gelmektedir. Günümüzde erkek eşcinsel için "gey", kadın eşcinsel için "lezbiyen" terimleri kullanılmaktadır (KAOS GL, 2017; TODAP, 2017). Eşcinsel oluşu, bir kişinin sahip olduğu niteliklerden sadece bir tanesi olmasına rağmen genellikle en temel niteliği olarak değerlendirilmekte (Zastrow ve Kirst-Ashman, 2015), heteroseksüeller için ise cinsel yönelim bu kadar öne çıkarılmamaktadır. Bunun kaynağında ise heteroseksüelliğin "norm" olarak kabul edildiği heteronormatif toplumsal yapılar içerisinde "norm dışı" sayılan eşcinselliğin daha fazla dikkat çekmesi rol oynamaktadır (TODAP, 2017).

Cinsel yönelim kimliğinin gelişimi üzerine çalışan uzmanlardan Vivien Cass (1984) eşcinsel ve biseksüel bireylerin cinsel yönelim kimliklerinin gelişimindeki farklı süreçler ve zorluklar üzerine bir model geliștirmiștir. Cass'ın modeline göre, bireyin kendi cinsel yönelimini fark ettiği ilk an itibariyle öncelikle kimlik karışıklığı yaşanmakta sonra da sırasıyla kimlik karşılaştırması, kimliği hoş görme, kimlik kabulü, kimlik gururu ve kimlik sentezi yaşanmaktadır. $\mathrm{Bu}$ modeldeki aşamalar tüm bireylerde aynı şekilde, birbirini sırayla takip eden sabit bir süreç olmaktan ziyade her bireyde kendine özgü şekillerde işleyen, esnek, hayat boyu sürebilen ve dolayısıyla kişinin mutluluğu ve öznel iyi oluşuyla bağlantılı bir süreç olarak karşımıza çıkmaktadır. Bu süreç aşağıdaki gibi özetlenebilir:

- Kimlik Karışıklığı Evresi: Bu evre, kişinin kendisiyle aynı cinsiyet kimliğine sahip bireylere yönelik ilgisinin farkına varmasıyla başlar. Kişi (heteronormatif bir toplumsal ortamda) kendisine yüklenmiş olan heteroseksüel kimliği ile eşcinsel hisleri arasında kalarak sıkıntı yaşayabilir.

- Kimlik Karşılaştırması Evresi: Kişi bu evrede heteroseksüel kimlikle kendi yönelimi arasında karşılaştırma yapmaya başlar. Heteroseksüel kimliği kaybetmeye yönelik hissedilen "yas”, bu evrenin önemli noktalarındandır.

- Kimliği Hoş Görme Evresi: Bu dönemde eşcinsel yönelim tam kabul edilmemiş olsa da bu durum kişi tarafından hoș görülebilir hale gelir. LGBTi kültürünün keşfi ve ilk partner yakınlaşmaları bu dönemde başlar.

- Kimliği Kabul Evresi: Bireyin kimliğini normal olarak kabul etmeye başladığı dönemdir. Daha derinlikli yakın ilişki arayıșları bașlar.

- Kimlikten Gurur Duyma Evresi: Önceki süreçte artmaya başlayan heteronormatif topluma ve ayrımcılığa yönelik öfke, eșcinsel kimlikle gurur duyma tepkisini doğurur.

- Kimlik Sentezi Evresi: Bu son evrede kiși cinsel yönelimini mevcut kimlik özelliklerinden sadece biri olarak görmeye başlar ve ne gereğinden fazla ne de az 
önem verir. Kimlik çatışması son bulur, ilişkilerini cinsel yönelime göre değil sevgi ve destek temeline göre düzenler.

Lezbiyen, Gey ve Biseksüel Kimlik Ölçeği'nin Türkçe versiyonunun geliştirildiği çalışmada; ölçeğin psikometrik özellikleri Türkiye'deki LGB bireylerin katılımıyla incelenmiştir (Kemer ve ark., 2017). Çalışma sonucunda, LGB bireylerin heteroseksüellere üstünlük bakış açısının, kimlik olumlaması ile pozitif ilişki içinde olduğu görülmüştür. Ayrıca kimlik olumlama eğiliminin izolasyon duygularıyla da pozitif yönde ilişkili olduğu tespit edilmiştir. Söz konusu çalışmada, "Kimlik Üstünlügü" ve "Kimlik Olumlaması" arasındaki güçlü pozitif ilişki, araştırma katılımcılarının Türkiye genelinde aktivist olarak nitelendirilen LGBTİQ gruplarından olmaları nedeniyle şu şekilde yorumlanmıştır: LGB kimlikleri ve hakları konusundaki aktif mücadeleye katılımları ve grup dayanışmaları; heteroseksüel kimlik karşısındaki üstünlük algılarının oluşmasını desteklemektedir. Kolektivist bir kültürde olmak, endişelerle birlikte aynı zamanda birbirini desteklemeyi de beraberinde getirmektedir. Dolayısıyla katılımcıların LGB kimliklerine yönelik olarak güven ve gurur duyguları hissetmeleri anlamlı bulunmuştur. Sonuç olarak bu araştırmada yer alan katılımcıların cinsel yönelim kimliklerine karşı güçlü bir olumlama yaklaşımı içinde oldukları görülmüş ve bu bulguların LGB kimlik gelişiminin kısmen sosyokültürel süreçler tarafından belirlendiğini öne süren çağdaş modelleri destekler nitelikte olduğu ifade edilmiştir.

Eşcinsel ilişkilere dair bazı çalışmalarda, geylerin gelişigüzel cinsel ilişkiye girme olasılığının lezbiyenlere göre daha fazla olduğundan söz edilmektedir (Walther ve Poston, 2004). Bununla birlikte Hyde ve DeLamater (2011) pek çok geyin uzun süreli ilişkiler kurduğunu da belirtmektedir. Yaşamın ileri dönemlerine yönelik çalışmalar içerisinde az da olsa 65 yaş üzeri lezbiyen ve gey bireylerin yaşllılı gereksinimleri üzerine olanlar da mevcuttur. $\mathrm{Bu}$ araştırmaların bir kısmında eşcinsel bireylerin yaşlanmaktan çok bir partner ile birlikte yaşlanmayı ve böylece yalnızlıkla baş etmeyi daha çok önemsedikleri görülmektedir (Berger, 1982). Fredriksen-Goldsen ve Muraco'nun (2010) yaptıkları analizde 1980 ve 1990'larda eșcinsellerle ilgili özellikle yaşlılık dönemine dair yapılan araştırmalarda gey ve lezbiyenlerin yaşlandıkça kendilerini cinsel olarak çekici hissetmemeleri ve depresif duygularının arttığı ifade edilmiştir. Bununla birlikte tam tersi sonuç veren alan araştırmalarına da bu analizde yer verilmiştir. Alanda yapılan pozitif psikoloji odaklı araştırmalarda da yaşlanma döneminde sağlıklı sosyal desteği olan ve cinsel yönelimini kabullenmiş ve açık yaşayan gey ve lezbiyenlerin, yaşam doyumu ve özsaygı düzeyleri diğerlerine göre anlamlı olarak daha yüksek bulunmuştur. Ayrıca eșcinsel bireylerin hayatında "seçilmiş ailelerin" yani bireyin cinsel yönelimini kabul eden sonradan oluşturulmuş manevi ailelerin varlığının da öznel iyi oluşu olumlu şekilde etkilediği gözlemlenmiştir. Türkiye'de lezbiyen, gey ve biseksüellerle (LGB) yapılan bir araştırmada da 
(Toplu-Demirtaş ve ark., 2018), öz-şefkatin, aileden ve yakın kişilerden algılanan sosyal destek ile öznel iyi oluş arasındaki ilişkilere aracılık ettiği tespit edilmiştir. Bu çalışmada, hem algılanan sosyal destek hem de öz-şefkat, LGB bireylerin öznel iyi oluşunun önemli bileşenleri olarak ortaya çıkmıştır.

Eşcinsel ve biseksüel bireyler, homofobi ve ayrımcılık gibi ciddi sorunları deneyimlemekte (Zastrow ve Kirst-Ashman, 2015), heteroseksüel akranlarına göre daha stresli yaşam olaylarıyla karşılaşmakta ve genel olarak daha az sosyal destek alabilmektedirler; bu da eşcinsellerin heteroseksüel akranlarına göre daha fazla ruh sağlığı zorlukları yaşama sebeplerinden birini oluşturmaktadır (Safren ve ark., 2001). Yaşlı LGBTİ bireylerin yaşam kalitelerini yükseltecek politikaların geliştirilmesi amacıyla özellikle ABD'de ve Avrupa ülkelerinde araştırmalar yapılmaktadır. The Williams Institute'un raporuna (Choi ve Meyer, 2016) göre, LGBTI bireyler heteroseksüel bireylere göre sağlık hizmetleri ve sosyal desteğe erişimde daha fazla sorun yaşamaktadırlar ve bu nedenle heteroseksüel yaşıtlarına göre zihinsel ve fizyolojik sağlıkları daha kötü olabilmektedir. Brennan-Ing ve arkadaşlarının (2011) 200'den fazla 60 yaş üzeri LGBTİ birey ile yaptıkları araştırmaya göre, yaşlı LGBTİ bireyler seçilmiş aile olarak tanımladıkları arkadaş odaklı sosyal destek gruplarına sahiptirler ve heteroseksüel bireylere göre biyolojik akrabalarıyla daha az ilişkileri bulunmaktadır. Yapılan başka bir araştırmaya göre (Fredriksen-Goldsen ve ark., 2010) yaşlı LGBTİ bireylerin heteroseksüel akranlarına göre bir ilişki ya da evlilik içinde bulunma oranları daha düşüktür, daha az sayıda çocuğa sahiptirler ve evlerinde yalnız yaşama oranları daha yüksektir. Araştırmaya katılan LGBTİ bireylerin yüzde 74'ü ruh sağlığını iyi olarak tanımlamış ve yüzde 74'ü de yaşamını doyumlu olarak tarif etmiştir. Katılımcıların yüzde 31'inde klinik seviyede depresyon semptomları bulunmuştur, yüzde 53'ü de yalnızlık hislerinden bahsetmiştir.

Buraya kadar belirtilenlerden hareketle, orta ve ileri yaşlardaki LGBTİ bireylerin heteroseksüel akranlarına nazaran daha olumsuz ve zorlayıcı yaşam koşulları içerisinde oldukları, buna karşın bu zorlayıcı koşullarla nasıl baş ettiklerine ve/veya bunları nasıl anlamlandırdıklarına dair oldukça sınırlı sayıda çalışmanın mevcut olduğu görülebilmektedir. Türkiye'de ise bu konuda yapılan çalışmalar neredeyse yok denecek kadar azdır. Diğer yandan, orta ve ileri yaşlardaki LGBTI bireylerin yaşam kalitelerini yükseltecek politikaların geliştirilebilmesi için bizzat konunun öznesi olan bireylerin kendi yaşam kalitelerini, yaşam doyumlarını ve/veya öznel iyi oluş hallerini nasıl anlamlandırdıklarını ve açıkladıklarını anlamak oldukça elzemdir. Böyle bir anlayış çerçevesinde, bu çalışmada, orta yetişkinlik dönemindeki geylerin öznel iyi oluşlarını nasıl açıkladıklarını ve bu açıklamalarında hangi söylemlerin (açıklayıcı repertuarlar) öne çıktığını anlamak amaçlanmıştır. 


\section{YÖNTEM}

\section{Katılımcılar}

Araştırmanın katılımcıları amaçlı örnekleme tekniğine (Yıldırım ve Şimşek, 2013) göre belirlenmiş, bu çerçevede 45-62 yaşları arasında, İstanbul'da ikamet eden, farklı eğitim düzeyinde olan ve kendini "gey" olarak tanımlayan 10 kişi ile bireysel görüşmeler gerçekleştirilmiştir (Bkz. Tablo 1). Nicel araștırmalardan farklı olarak, nitel araștırmalarda katılımcıların sayısından ziyade veri miktarının önemli olduğu; az kişiyle yapılan derinlemesine görüşmelerden zengin ve derinlikli verilere ulaşmanın mümkün olduğu belirtilmektedir (Arkonaç, 2014; Yıldırım ve Şimşek, 2013). Buna göre, 40 dakikadan az olmayan, ortalama 15 kişilik görüşmeler yeterli verinin elde edilmesini sağlayabilmektedir. Veriler belli bir doygunluğa ulaşınca, yani veriler kendini tekrar etmeye başladığında, veri toplama süreci sonlandırılabilir (Yıldırım ve Şimşek, 2013). Bu çalışmada ise özellikle toplumsal önyargı ve damgalama endişesiyle araştırmalara katılım konusunda çekinceleri olan bir grupla çalışılmasından dolayı katılımcı sayısı 10 kişi ile sınırlandırılmış; bununla birlikte elde edilen verilerin yeterli doygunluğa ulaştığı görülmüștür.

Katılımcılara kartopu yöntemiyle ulaşılmıştır. Görüşmelerin öncesinde katılımcılara araştırma hakkında bilgi verilmiş, görüşmenin ses kayıt cihazı ile kaydedileceği belirtilmiş ve katılımcılardan çalışmaya gönüllü olarak katıldıklarına dair sözlü onam alınmıştır. Araştırmanın yapıldığı dönemde, ilgili kurumda, klinik örneklem içermeyen ve niteliksel yöntemle yapılan tez çalışmaları için zorunlu bir Etik Kurul değerlendirmesi söz konusu olmadığı için bu makaleye temel teşkil eden çalışmanın bir etik kurul kararı bulunmamaktadır.

\section{Tablo 1}

Katılımcılara ilişsin demografik bilgiler

\begin{tabular}{ccll}
\hline Katılımc & Yaş & Meslek & İlişki durumu \\
\hline K1 & 53 & İlaç sektöründen emekli & İlşkisi yok \\
K2 & 45 & Bilgi işlemci / şu anda çalışmıyor & İlişkisi yok \\
K3 & 45 & Tekstilci / şu anda çalışmıyor & 10 senelik İlişkisi var \\
K4 & 62 & Psikolog & İlişkisi yok \\
K5 & 50 & Doktor & İlişkisi var \\
K6 & 45 & İletişimci & İlişkisi yok \\
K7 & 54 & Psikolog & 18 senelik İlişkisi var \\
K8 & 53 & Tekstilden emekli ve gey barda şarkı söylüyor & İlişkisi yok \\
K9 & 46 & Eğitim şirketinde çalışıor & İlişkisi yok \\
K10 & 47 & Kafede servis görevlisi & İlişkisi yok \\
\hline
\end{tabular}

\section{Veri Toplama Araçları ve Uygulama}

Araştırmanın verileri, niteliksel bir veri toplama tekniği olan yarı-yapılandırılmış görüşmeler yoluyla toplanmıştır. Yarı-yapılandırılmış görüşmelerde, bazı genel sorular araştırmacı tarafından önceden hazırlanır, ama görüşme katı bir şekilde bu sorular üzerinden 
soru-cevap tarzında yürütülmez. Görüşmeler katılımcıların yönlendirmesine ve derine inmesine açık bir şekilde ilerler, böylece katılımcılar gündelik bir etkileşimdeki gibi kendi anlamlandırmalarına göre konuşma imkânı bulurlar (Smith, 1995; Arkonaç, 2014).

Araştırma kapsamında, esas görüşmelere hazırlık amacıyla öncelikle bir pilot görüşme gerçekleştirilmiştir. Pilot görüşmede "öznel iyi oluş” kavramının psikoloji alanından olmayan katılımcıya anlaşılmaz geldiğinin görülmesi üzerine esas görüşmelerde bu kavramın yerine "mutluluk" ve "yaşam doyumu" kavramlarının kullanılmasına karar verilmiştir. Pilot görüşmede, ayrıca, soruların çeşitlendirilerek görüşmenin derinleştirilebileceği görüldügü için öznel iyi oluşun parametreleri olan ilişkiler, kişilik yapısı, inanç, eğitim seviyesi, gelir düzeyi ve sağlığın mutlu ve doyumlu hissetme ile ilișkisini içeren sorular eklenmiștir.

Buna göre, görüşmeler aşağıdaki sorular üzerinden yarı-yapılandırılmış bir şekilde yürütülmüştür:

1. Kendinizi biraz tanıtır mısınız?

2. 45-65 yaş arası orta yetişkinlik dönemi olarak adlandırılıyor. Kendi açınızdan düşünecek olursanız; içinde olduğunuz bu dönemde kendinizi iyi hissedip hissetmediğinize, mutlu olup olmadığınıza, yaşamınızı doyumlu hissedip hissetmediğinize dair fikirleriniz nelerdir?

3. Mutluluğunuzu ve yaşam doyumunuzu nelerin etkilediğini düşünüyorsunuz? Kişilik özellikleriniz, eğitim düzeyiniz, iş durumunuz, gelir seviyeniz, sağlık durumunuz gibi niteliklerin mutluluğunuza etkisi açısından neler söyleyebilirsiniz?

4. Herhangi bir inanca sahip olarak tanımlıyor musunuz kendinizi? Sizce inancın sizin yaşam doyumunuz veya mutluluğunuzla nasıl bir ilişkisi var?

5. Aile, arkadaş ve partner ilişkileriniz, mutluluğunuz ve yaşam doyumunuz açısından nasıl bir etkiye sahip sizce?

6. Cinsel yöneliminizin mutluluğunuza ve yaşam doyumunuza etki edip etmediğine dair fikriniz nedir? Bu konuda neler söyleyebilirsiniz?

7. Geçmiş dönemlerinize göre şu an içinde bulunduğunuz dönemde mutluluğunuzu veya yaşam doyumunuzu etkileyen kavramlarda değişen şeyler var mı sizce? Eğer varsa, bu değişikliklerin neyle ilgili olduğunu düşünüyorsunuz? Değişen bir şey yok ise bunu nasıl açıklarsınız?

8. Eklemek istediğiniz herhangi başka bir şey var mı? 
Her bir katılımcı ile ortalama birer saatlik yüz yüze görüşmeler gerçekleştirilmiş, görüşmelerin ses kayıtları alınarak daha sonra bilgisayar ortamında deşifre edilmiştir. "Bulgular" kısmında sunulan alıntılarda katılımcılar "K", görüşmeci ise "G" harfleriyle kodlanmıştır. Alıntıların en başında katılımcının yaşı, iş durumu ve ilişki durumuna dair bilgi verilmiştir.

\section{Veri Analizi}

Bu çalışmada niteliksel bir analiz tekniği olan "söylem analizi" kullanılmıştır. Daha spesifik olarak söylenirse, görüşme metinleri, Wetherell ve Potter (1988) tarafından geliștirilen “açıklayıcı repertuar" yaklaşımına göre analiz edilmiş ve katılımcıların açıklamalarına kaynaklık eden "açıklayıcı repertuarlara" ulaşılmıştır.

Söylem, söylemsel psikoloji açısından, duruma konumlandırılmış dil karşıllı̆ı olarak kullanılmaktadır ve dilin sözlü ya da yazılı kullanımıdır (Balcı, 2016). Söylem analizi de karşılıklı konuşma ya da her türlü yazılı metinde konuşmacının ya da yazarın açıklamalar inşa ederken kullandığı dil tarzının incelenme yöntemidir (Burr, 2012). Balcı (2016) söylem analizini bir söylemin yapısını ve biçimini göstermeyi amaçlayan metinsel analiz olarak tanımlamış ve dilin ve yazılı metinlerin davranışı nasıl şekillendirip etkilediğini, nasıl anlam inşa ettiğini araştırmayı hedeflediğini belirtmiştir. Söylem analizi sadece kimin ne söylediği ile ilgili değil, konuşurken kullanılan tüm sembollere, jargonlara ve metaforlara odaklanarak hiyerarşik güç ilişkilerini açı̆̆a çıkarma hedefindeki bir analiz metodudur (Akturan ve Baş, 2008).

Açıllayıcı repertuarları ise dünyaya dair açıklamalarımızı ve anlamlandırmalarımızı inşa etmek için kullandığımız söylemsel kaynaklar; açılklamalarımıza kaynaklık eden "inşa blokları" olarak tanımlayabiliriz (Wetherell ve Potter, 1988). Bu inşa blokları, katılımcıların üzerine konuşulan konularda kendi anlamlandırmalarını inşa etmelerine kaynaklık eden belirli açıklama biçimleri taşırlar ve birbirlerine alternatif açıklama biçimlerini de barındırabilirler. Bu nedenle Burr'un (2012) tanımına göre açıklayıcı repertuarlar, kişilerin istedikleri amaca (ikna etme, meşrulaştırma, onaylanma, haklı çıkma, vb.) ulaşmak için çeşitli açıklamaları çekip alabildikleri bir "alet çantası" gibidir. Alet çantasında her ihtiyaca göre farklı bir açıklayıcı repertuar bulunmakta ve zamanı geldiğinde kullanılmakta; böylece her seferinde gerçeklik yeniden ve farklı şekillerde inşa edilmektedir.

Wetherell ve Potter'a (1988) göre, açıklayıcı repertuarlar, metinler arasında tekrar eden ve meşrulaştırma, ikna etme, dayanak sağlama gibi işlevleri olan açlklama biçimlerinin, tariflerin, metaforların ve kalıpların fark edilmesiyle kendilerinden söz edilebilir hale gelirler. $\mathrm{Bu}$ doğrultuda, analiz için, görüşme metinleri her bir araştırmacı tarafından tekrar tekrar okunarak onlara iyice aşina hale gelindi ve böylece araştırmanın konusu ile ilgili olarak konuşmalarda öne 
çıkan ve/veya tekrar eden açıklama biçimleri görülebilir hale geldi. Sonrasında, her bir araştırmacının belirlediği tipik açıklama biçimleri, kalıplar, vs. bir araya getirildi ve bunlardan hareketle açıklayıcı repertuarlara ulaşıldı. Örneğin, katılımcıların uzun süreli ilişkiye sahip olmayı/olmamayı tipik olarak mutlulukla veya yaşam doyumuyla bağlantılandıran açıklamalarından hareketle "uzun süreli partner ilişkisi" diye adlandırdığımız repertuara ulaşıldı.

Nitel araştırmada geçerlik ve güvenirlik, nicel araştırmadan farklı bir şekilde ele alınmaktadır. Yıldırım ve Şimşek (2013), nitel araştırmada iç geçerlik için "veri kaynakları ile uzun süreli etkileşim”, "derinlikli veri toplama”, "veri kaynaklarının (katılımcı niteliklerinin) çeşitlendirilmesi", "birden fazla araştırmacının analiz sürecine katılımı"; dış geçerlik içinse "doğrudan alıntıların sunulması" ve "amaçlı örneklem" gibi stratejiler önermektedir. Nitel araştırmada güvenirlik ise araştırmanın en başından itibaren araştırma ile ilgili tüm prosedürlerin, katılımcıların, veri toplanan sosyal ortamların ve analizde kullanılan çerçevenin açık ve net biçimde ortaya konulması ve bunlar arasında tutarlılık sağlanmış olmasıdır. Analiz sonucunda elde edilen verilerin benzer araştırmalardan elde edilen sonuçlarla karşılaştırılarak teyit edilmesi de güvenirlik için kullanılan yaygın stratejilerden biri olarak ifade edilmektedir.

Bu çalışmada da geçerlik ve güvenirlik için yukarıda belirtilen stratejiler kullanılmıştır. Her şeyden önce, araştırma, LGBTİ topluluğu ile uzun süreli etkileşimi bulunan iki araştırmacı tarafından gerçekleştirilmiş, derinlikli ve doğal veri elde etmek için derinlemesine görüşme tekniği kullanılmış, katılımcı grubu amaçlı örneklemeye uygun olarak belirlenmiş olmakla birlikte kendi içinde eğitim düzeyi, meslek ve yaş çeşitliliğini yansıtacak şekilde belirlenmiş, açıklayıcı repertuar yaklaşımına göre analiz edilen verilerin sunumunda doğrudan katılımcı açıklamaları detaylı bir şekilde verilmiş, analiz sonuçları benzer araştırmalardan elde edilen sonuçlarla karşılaştırılarak teyit edilmiştir.

\section{BULGULAR}

Görüşmelerin analizi sonucunda, katılımcıların mutluluk ve yaşam doyumu ile ilgili açıklamalarına kaynaklık eden yedi farklı repertuara ulaşılmıştır; "uzun süreli/güvenli partner ilişkisi”, "cinsel haz", "gençliği olumlama ve beğenilme arzusu”, "aile ve arkadaşlar", "başkalarına fayda ve deneyim aktarımı", "özgürlük" ve "kendini kabul”. Bununla birlikte, bu makalede, bunların tümünü detaylı bir şekilde sunmak için yeterli alan bulunmadığından dolayı, görüşmelerin bütününde özellikle öne çıkan "uzun süreli/güvenli partner ilişkisi” repertuarı sunulmaktadır.

Görüşmelerde katılımcılar, uzun süreli ve güvenli partner ilişkisinin hayatlarında kendilerini iyi ve mutlu, yaşamlarını doyumlu hissetmelerinde önemli olduğunu belirtmişlerdir. 
Uzun süreli ve güvenli bir partner ilişkisinin olmaması mutsuzluk sebebi olarak tarif edilmiş, güvenli bir ilişkiye ait olma ihtiyacı öne çıkarılmıştır. Bununla birlikte, katılımcıların açıklamalarına bakıldığında, geyler arasında uzun süreli ilişkilerin pek mümkün olmadığına dair varsayımlara ve inançlara sahip oldukları ve ayrıca yaşlanmanın getirdiği yalnızlık algısına dair açılamalarda bulundukları da görülmektedir.

Örneğin, aşağıdaki alıntıda K1, kendini kabulün arttığı ve sorgulamaların azaldığını hissettiği orta yetişkinlik döneminde, duygu durumunu başta mutlu olarak anlatmakla birlikte aslında ruhsal tatminin, hayat arkadaşlı̆̆ının öne çlktığı bir ilişkiyi mutluluğuyla direkt ilişkilendirmekte, partneri olmadığı için kendini yalnız ve mutsuz olarak tanımlamaktadır. Bağlılık ve sevgiyi yaşadığı bir partner ilişkisinin olmamasını aynı zamanda yaşam enerjisinin düşmesi ile de bağlı görmektedir. Ona göre bir partneri olursa yaşam enerjisi daha yüksek olacaktır. Eşcinsel olmanın, sürekliliği olan bir partnerlik ilişkisi kurmada heteroseksüellere göre 1-0 yenik olmayı getirdiğini belirten $\mathrm{K} 1$, aşka inancını yitirmemiş olduğunun da altını çizmektedir. K1 heteroseksüellere göre 1-0 yenik başlangıcın ve güvensizliğin sebebini ise eşcinsel yönelimlerini saklayarak geçmiş olan hayatlarının getirdiği şeffaf, dürüst ve dolayısıyla güvenilir olamama alışkanlığına bağlamaktadır.

\section{Alıntı-1 [Katılımcı-1, yaş 53, ilişkisi yok, emekli]}

K1: Yani şimdi ben aslında genel olarak hayatı seven kendini mutlu hisseden birisiyim. Ama bu benim cinselliğimle alakalı değil. Cinselliğim işin içine girdiği zaman tam tersi mutsuzum yalnızım. Çok uzun zamandır sevgilim olmadı. (...) bir şekilde hayatında dengeyi kurduğunda işte en çok istediğim şey hayatımı paylaşacağım birinin olması ama onu da bulamıorsun. Artık bu iş böyle şeye geliyor ve fiziksel beğeni olmuyor ya da ruhsal uyuşmazlık durumu söz konusu oluyor. Fiziksel beğendiğin birinin kafasını beğenmiyorsun kafasından çok hoşlandığı birisini fiziksel olarak çekici bulamıyorsun gibi gibi yani. Öyle.

\section{$[\cdots]$}

K1: Şimdi mutluluk aslında bence iki türlü mutluluk var bir tanesi kendi kendine olan mutluluk yani depresyonda olmadığın zaman işte baktığında ne güzel bugün güneş var, hava çok güzel dediğinde içinin böyle bir daha bir neşeli olması evet mutlusun ama bir yandan düşündüğün zaman oturup düşündüğünde hayatım nereye gidiyor, hani geçmiş değil hani günümüz ve gelecek açısından baktığın zaman biraz böyle mutluluk sanki gölgeleniyor gibi geliyor bana. Onu da neye dayanarak söylüyorum? Şimdi yani ben enerjiye çok inanan birisiyim hani kendi başıma enerjimin yüksek olduğunu ama o enerjinin tek başına beni hayatta tutmaya ya da hayatın zorluklarıyla baş etmeye 
yetmeyeceğine inanıyorum. Bir şekilde ikili ilişkilerin insanın yaşam enerjisini yükselten ilişkiler olduğuna da inanıyorum ve ruh eşi mi denir buna işte fiziksel eşi mi denir artık ne denirse artık bu hayatındaki insanın olduğunda bana vereceği şey büyük ihtimal o mutlulukla birlikte gelecek olan pozitif enerji. Hani yaşam enerjimin daha yüksek olmasını beklerim ama değil. Hani o yaşam enerjim düşük ve epey bir süredir de düşük. Hani mutlulukla alakalı da aklıma bunlar geliyor. Evet hani tatmin edici bir hayatım var genel anlamda. İşin manevi boyutunu bir kısmını yok sayar maddi boyutunu düşünürsek evet tatmin edici bir hayatım var. Ama yeterli mi. Tabii ki değil.

Araştırmacı: Ne yeterli hissettirirdi?

K1: Yani duygusal anlamda bağlılık hissedeceğim aidiyet ve sevgi yaşayabileceğim bir ilişkimin olmasını isterdim, onunla daha da mutlu olacağıma inanıyorum öyle bir şey olursa.

Aşağıdaki alıntıda ise K2, güven kavramını ilişkilerde en temel değer olarak tanımlamakta ve yaşadığı güvensizliklerin başkalarına karşı duvar örmesine neden olduğunu, güvenmenin daha zorlaştığını belirtmektedir. Geçmişte gey buluşma mekânlarında ilgilendiği ve kendisiyle ilgilenen kişilerle günümüzdeki gey mekânlarında karşılaştıklarını kıyaslamaktadır. K2'ye göre günümüzde karşılaştı̆̆ genç geyler, eskiye göre daha ısrarcı olmakta ve kendisinin ise arayışının gündelik ilişki olmaması nedeniyle artık bu mekânlara gitmediğini ifade etmektedir. Hayatında güvenli bir partnerlik ilişkisini öznel iyi oluşu açısından önemli bulmakla birlikte eskiye kıyasla ümidini de düşük tanımlamakta, güven sorununun altını çizmektedir. İçinde bulunduğu gey ortamında güvenli ilişkinin kesinlikle olamayacağına dair şahitliği olduğunu da söylemektedir.

\section{Alıntı 2 [Katılımcı-2, 45 yaşında, ilişkisi yok, şu anda çalışmıyor]}

K2: (...) bizim zaten en büyük problemimiz o, güven. Niye? Çünkü sen birisinden hoşlanacaksın bir partner filan yaşam arkadaşı diyelim güvenmek istiyorsun bu sefer önceki bu ortamda yaşamış olduğun güvensizlikler aklına geliyor. Çünkü acaba bu da mı öyle kendi şeyince kendince bir duvar örüyorsun çünkü kimseye güvenmiyorsun. Acaba o da mı öyle acaba bu da mı böyle çünkü insanların bilirsin hani şimdi şeyi vardır kendilerini ele verme yöntemleri vardır ya da sen çok dikkatliysen anlarsın. Bazen insanlara bir lafiyla anlıyoruz bazen hoşuna gittiği için bunları tolere ediyorsun, görmezden geliyorsun ama sonuçta baktığınız zaman diyelim güvensizlik var ne zamanki güvensizlik olayın içine girdiği anda her şey bitiyor (...)

$[\cdots]$ 
K2: Çok şey. Ve o zamanlar insanlara çok daha fazla güveniyordum şimdi insanlara hemen hemen güvenim yok. Yani insanlar ayrılıyor artık bazısı sadece seks istiyor bazısı duygusallık istiyor bazısı ikisini beraber istiyor işte. Şimdi kendini keşfediyorsun güzel bir şey yaşıyorsun kendince hoşuna giden de oluyor güzel bir şey yaşıyorsun ve bu periyot sık bir periyot. Düşünsene yeni bir şey almışsın ve onu sıkça kullanıyorsun gibi bir şey. Ondan sonra zaman geçtikçe şunu anlıyorsun kırklı yaşlara geldiğin zaman aslında aradığım yaş itibariyle artık hani bir kişi olsun tam olsun moduna giriyor. Zamanla bunu aramaya başlıyorsun. Bunu aramaya başladığın zaman karşına çıkan insanlar iyi olmayabiliyor çünkü o zamanki insanlar çok daha usturuplu edepliydi.

$[\ldots]$

Araştırmacı: Güvenden çok bahsettik ya güven ne demek senin için? K2: Güven yani koşulsuzca ama acaba neden niçin olmadan bir arkadaşına kendini açabilmen teslim edebilmen. (...) Benim sevdiklerimle aramda art niyet olmaması gerekiyor. Yani kıskançlık olmaması gerekiyor ama ana temelde saygı olması gerekiyor. Saygı olmazsa her şey birbirini tetikliyor. Saygısı olması lazım tekrar bir şey değil yani aynı evin içindeysek de gözünün içine baktığım anda ne hissettiğini anlayabiliyorum o da benim. Yani kısacası ne yapıp yapamayacağı neye kızıp neye kızmadığını neye değer verip neye vermediğini (...)

Așağıdaki alıntıda ise K3'ün 10 yıllık ilişkisinden söz ettiği görülmektedir. Dönem dönem mutsuzluklar getirmiş olmasına ve mevcut durumda cinsel açıdan 'açık ilişki' yaşıyor olmalarına -başka cinsel partnerlerle birlikte olma kararı almış olmalarına- karşın, 10 senelik ilişkisini karşılıklı yardım ve paylaşmanın olduğu, zor dönemlerde birbirlerine destek verdikleri, vazgeçmek istemediği, gerektiğinde ayrılmamak için emek sarf ettiği, güvenli bir alan olarak tanımlamaktadır. K3, bu güvenli ilişkiyi devam ettirirken cinsel haz ve heyecanın başka ilişsilerde yaşanması özgürlüğü konusunda da partneriyle ortak karar alarak birlikteliklerinde tensel paylaşımdan daha önemli bağlayıcı unsurlar olduğunun altını çizmektedir.

\section{Alıntı 3 [Katılımcı-3, 45 yaşında, 10 senelik ilişkisi var, şu anda çalışmıyor]}

K3: ... bir partnerim var, 10 senedir var. Onla da çok fazla böyle. Onla da aslında çok zitız. Zor ya. İnanılmaz ukala bir tip. Burnu düşse eğilip almaz. Çok, benden daha fazla ukala. Biraz patavatsızdır. Susturamazsın bir konuşsa. Biraz Allahım nasıl anlatsam. Aslında çok zıtız. Ben güya bu ilişkide ağır ve olgun olan tarafım. 0 daha genç ve hoppa olacak; ama öyle değil. Bi yerde biraz fazla; çok bilmiş. Çok kavga ediyoruz; çok zıtlaşıyoruz. Sonuçta tabii ki bir sevgi var temelde. Mutluyuz ayrı konu. Şu anda 10 yıl sonra aramızda çok seks ilişkisi kalmadı. Belli bir dönemden sonra açık ilişkiye geçtik. Bunların hepsinin aşama 
aşama yaşam üzerinde etkisi var. İlk birkaç yll farklıydı; sonra birbirimizi ittiğimiz bir dönem oldu. Ayrılmaya karar verdik. Dediğim gibi, açık ilişki diye bir ilişkiye geçtik. Bunları bildiğini varsayıyorum. Ondan sonra yeniden böyle iyi, sonra tekrardan bir itme dönemi. Bir dönem tamamen ayrıldık. Gitti başkalarıyla bir şeyler yaşamaya kalkıştı; eline yüzüne bulaştırdı. Sonra yine döndü. Bunların düşünüyorum şimdi mutluluğuma nasıl bir etkisi var. Yani, beni mutsuz ediyor herhalde. Şimdi bunlar üzerinde düşününce böyle söylüyorum. Yoksa yaşadığımda șey yok... Ne diyim yani? Böyle tek bir tane kelime ile çıkmıyor ortaya. Elbette olumlu etkisi var; ama beni çok mutsuz ettiği zamanlar oldu. Ben de onu ettim muhtemelen. Ama sonuçta gece olduğunda yine sarılıp birlikte yatıyoruz. Böyle de bir şey var. Çünkü çok ağır kavgalar ediyoruz. Yatağa girdiğimizde, her şey bitiyor seks olmasa da. Hiçbir şey yokken bile. Zaten 2 tane kedi var evde. Onlar geldiğinde olay bitiyor. (Gülüyor)

$[\cdots]$

K3: Sürekli o konuda da laf yiyoruz, o ayrı konu. Bir ayrılıyorsunuz bir barışıyorsunuz; ama sonuçta bu da şey, bu da tecrübelerden birisi. Ayrılıp geri dönmek. Ben direndim; ben korumaya çalıştım. Ki git ne yapıyorsan yap; ama sonra akşam evinde olmayı bil dedim yani. Bunu söylerken belki kendim mutsuz oldum; ama ilişkiyi kurtardım belli bir süre sonra. Bunlar yaşandı yani.

Araştırmacı: 0 zaman ilişkinin varlığı sadakatten daha önemli? Yani o kişi ile ilişki?

K3: ... fakat o kişinin hayatından olmasından memnunsun. Konuştuğunuz konular, hayata bakış açınız, birbirinizle olan yardımlaşmanız dahi, buna maddiyat da girebilir. 0 seni koruyup kolluyor; sen onu koruyup kolluyorsun. Ne biliyim ben işsizim o yardım ediyor; o işsiz ben yardım ediyorum. Bundan bahsediyorum. Sonuçta birinin olması seni memnun ediyor. Ki şey olarak da var; ruh uyumu da var. Aynı şeylere gülebiliyorsunuz. Aynı tarz filmleri seviyorsun. Ama cinsel olarak o heyecan gidiyor. Zorlamayla da olmuyor. Tamam ne yapalım diyorsun. Birbirimizi bulduk kaybetmeyelim; arada da bir heyecan da yașayalım madem. 0 anlamda. Bunu anlatmak zor oluyor. Hâlâ bile. 10 yll sonra bile.

K3'e benzer şekilde, aşağıdaki alıntıda K7 de partneriyle olan ilişkisini paylaşımın önemli olduğu, güvenli hayat arkadaşlığı olarak hissettiğini belirtmekte ve aynı zamanda bu ilişkiyi aile ile özdeşleştirmektedir. Katılımcı, ihtiyaç duyduğunu belirttiği ve süreklilik içeren bağı -yani ait olma hissini- bu ilişki üzerinden sağladığını belirtmektedir.

\section{Alıntı 4 [Katılımcı-7, 54 yaşında, 18 senelik iliş̧kisi var, psikolog]}


K7: ... birliktelikler ilişkiler yani mutlu hissettiren. Partner de hani artık şey gibi bir noktadan sonra ayrılmayacağım birlikte devam edeceğim birisi gibi. Zaman zaman ayrılmak istediğim dönemler olur çünkü çok zor şeyler yaşadım falan birtakım uyuşmazlıklar birtakım şeyler ama şimdi bakınca hani şey gibi bir tür hayat arkadaşı gibi oluyor. Artık hani bu şey gibi ailem gibi işte yani aile dediğimiz şey de bu değil mi aslında. Ama tabii bir kan bağı olmasa da hani bilmem şöyle hissediyorum, hani hayatta birlikte geliştiğin ve birlikte devam edeceğin birisi gibi geliyor. Yani aile efradından insanlardan da bahsettiğimizde aynı şey değil mi? Sonuçta yani ilişkinin devam edeceği ve kopmayacağı bir şey bir bağ. Şey gençken o bağları koparmak ve yalnız hareket etmek istiyorsun. Sonra dönüp o bağları tekrar şey yapıyorsun, sarılıyorsun.

Araştırmacı: O bağlar ne getiriyor size?

K7: Neden ayrılmak istemedim galiba şey gibi hayatta bir süreklilik, hayatın devam ettiğine dair bir şey. Hayatla kurduğum ilişkide önemli bir kişi bir o hayatınıza güven hissi veren bir şey. Seni sarıp sarmalayan bir şey. Valla şöyle oldu birlikte yaşadığım için partnerle daha fazla şey paylaşıyorsun. Çünkü birliktesin evdesin zamanın büyük bölümü iş dışında onunla geçiriyorsun o yüzden o seni daha fazla görüyor. Yani ona tabii ki, yani birlikte olsan da ondan gizlediğin yanlar olabilir. Gizlediğin yanlar demeyim de hiçbir şey aslında gizleyemiyorsun ama yine de insanın kendine ait birtakım sırları olur. Ama o herkesten çok seni dinliyor ve sen de herkesten çok onu tanıyorsun, böyle tuhaf bir bağ oldu. Konuşurken komik geliyor ama güzel bir şey. Güven duygusu veren bir şey. Hani güven duygusu aslında insanın kendiyle ilgili bir şey ama insanın hayatta birlikte devam edeceği birisi. Bir şekilde o hayatını idame ettirirken o da yanında yürüyeceğin birisi gibi hissediyorsun işte....

Aşağıdaki alıntıda, hâlihazırda ilişkisi olmayan K8, güvenli, sadakat içeren bir ilişkisinin olmasını istediğini ve bunun hayatındaki en büyük mutluluk kaynağı olacağını belirtmektedir. Bununla birlikte "gey camiada" sadakatin olmadığına dair tanıklığından da söz etmektedir. Hem sevgililiğe artık inanmadığını söylemekte hem de mutluluğunu öncelikli olarak olmasını istediği sevgililik ilişkisine bağladığını ifade etmektedir. Şu anda âşı olduğu kişiyle bir ilişki yaşamamalarına rağmen, ona olan aşkı nedeniyle 4 senedir cinsel tatmin için bile olsa bir başkasıyla temasa geçmediğini, o kişiyle ne olursa olsun yan yana olmanın hayatında çok önemli olduğunu belirtmektedir. Sadakate dayalı partnerlik ilişkisini, aynı zamanda yaş ilerledikçe endişelendiğini belirttiği yalnızlı korkusuna karşı da rahatlatıcı bir unsur olarak tanımlamaktadır. 


\section{Alıntı 5 [Katılımcı-8, 53 yaşında, ilişkisi yok, gey barda şarkı söylüyor]}

K8: Yetişkinlik döneminde ileriye yönelik işte insanların korkuları, korkularım var. Yani sonuçta bekâr bir insanım, geyim hadi toplumu tarafından tamamıyla böyle kabullenmiş bir durum değil, bizim yaşadığımız olay ha ilerde bende şey korkusu var bu yaş ve bundan sonrası için işte yalnız kalma korkusu var ya o ciddi anlamda korkutuyor beni. Onun dişında bir şeyim yok. yani sıkıntım yok, mutluyum hayatımda birinin olmasını da isterdim ama bu geçmişte yaşandı tabii böyle bir deneyim edindim, güvensizlik var insanlara karşı hele şu dönemde. Eskiden bundan 20 yll öncesine kadar ciddi anlamda bir sadakat vardı, sadakat vardı yeni sevgililer arasında ama şimdi o yok sevgilinin sevgilim dediği kişiye, geliyorlar gözümün önünde ben odağındayım yani merkezinde çalışıyorum, oradan herkesi görebiliyorum, sarmaş dolaştılar ama gözü ötekinde afedersin tuvalete kalktığında diğeri masadayken hemen diğerlerine hoşlandığı bakıștığı kişiye numarasını verip sevgilim dediği kişiyi aldatabiliyor dolayısıyla ben bunları gördüğüm için şeye karşı bir güvensizliğim var artık sevgililiğe inanmıyorum ben inanmıyorum sadakat yok çünkü insanlarda bizim ortamdaki insanlardan bahsediyorum gerçi bu ama heterolarda da vardır mutlaka ama bizim bu gey camiasında daha yoğunlukta olduğunu düşünüyorum.

Araştırmacı: Senin için önemli sadakat?

K8: Tabii ki çok çok önemli, çok önemli yani ben tek eşli ilişkiden yanayım bu hep böyle olmuştur günübirlik şeyler beni çok tatmin etmiyor çünkü ben duygu insanıyım yani öyle olduğunu düşünüyorum. Ben birini sevdiğim zaman inan ki bak bir örnek göstereceğim aramızda. Şu kişi A, 4 yıldır tanıyorum onu. Ben dört yıldır ona aşığım ciddi anlamda onunla hiçbir şey yaşamıyoruz, hiçbir şey yaşamıyoruz ama ben öyle o kadar çok seviyorum ki yani onu düşünerek uyuyorum kalkınca ilk aklıma o geliyor ve 4 senedir bu devam ediyor, böyle duygularımı biliyor. Paylaştım ama onun yapabileceği bir şey yok yani ama ben onu seviyorum diyorum o da beni sevmek zorunda değil çünkü bu biraz tiple alakalı. Yani mantık yok mantığıyla düşünen insanlar var tabii ki onlar da çıkar doğrultusunda çıkar doğrultusunda hareket ediyorlar. Ben öyle değilim. Ben 4 yıldır bu insana aşığım 4 yılda ben bir kimseyle, hiçbir şeyim olmadı, hiçbir şeyim olmadı.

\section{$[\ldots]$}

Araştırmacı: Seni en çok neler mutlu ediyor

K8: Ben işte öyle sevdiğim insanın yanımda olması en çok benim para da mutlu etmiyor yani bak biz bazen bununla tartışırız ki çok sık tartışırız ama bir gün sürer en fazla sonra hiçbir şey olmamış gibi ben yine ararım. Yani ben onunla küsken cidden hiç mutlu 
olamıyorum. Hiç mutlu olamıyorum. Yani dünya benim olsa gerçekten umurumda değil hiç. Beni bu çok mutlu ediyor bunun yanımda olması. Hiç gerisi boş

Son olarak, aşağıdaki alıntıda ise K5'in, mutluluğa dair açıklamalarında "yaşlanmayı" öne çıkardığı görülmektedir. K5, eskisi kadar enerjik hissetmeme ve yaşlanıyor olmanın kendisini mutsuz hissettirdiğinden, bu nedenle spor yaptığından ve botoks gibi işlemlere yöneldiğinden bahsetmektedir. Eskiye göre barlarda daha az ilgi görmesinin de kendisini yaşlı ve mutsuz hissettirdiğini ifade etmektedir. Bununla birlikte, gey camiada yaşlandıkça daha az beğenilmenin ve tercih edilmemenin heteroseksüel ilişkilerde olduğundan daha olağan olduğundan ve bir anlamda bunu "normal" karşıladığından söz etmektedir. Kendisi de "çirkinleşirse" veya "fitliğini kaybederse" şu anda mutlu olan ilişkisinin bozulacağını ve sevgilisinin onun terk edeceğini ifade etmektedir. Bu durumu ise gey camiada yaygın olan "olguncu" ve "çıtırcı" yaklaşımlar nedeniyle partnerler arasındaki yaş farkının genelde fazla olmasına bağlamaktadır.

\section{Alıntı 6 [K5, 50 yaşında, ilişkisi var, doktor]}

K5: ... eskiden fiziksel aktivitem daha iyiydi. Enerjim daha fazlaydı, fiziksel aktivitem düştü, eskisi gibi iyi değil, bu da otomatikman beni mutsuz ediyor, mutsuzluk kaynaklarından biri oluyor, spor yapıyorum işte onu eski kapasiteye ulaşmak için uğraşıyorum falan ama eskisi kadar fiziksel aktivitem yok. 0 bazen yaşlanıyorum kaygısı bende oluşturuyor. Ama diğer kaygların yanında daha az bir yüzde ile söyleyebilirim, öyle bir şeyim var evet hatta işte botoks yaptırdım alnıma, tekrar yaptırmak istiyorum, bazen de çok güzelleşmek için bir şeyler yapıyorum. Eskiden bara gittiğimde yüz kişi bakarken 3 kişi bira ısmarlarken şimdi 10 kişi bakıyor kimse bira ısmarlamıyor. Var yani öyle kaygılarım yaşlanmak filan (...)

Araştırmacı: Yaşlılık ne demek sizin için?

K5: Yaşlılık çirkinleşmek, fiziksel aktivitenin azalması demek. Albeninin azalması demek. Yaşlılık bence bu.

Araştırmacı: Peki bunun sizin cinsel yöneliminizle bir alakası var mı yoksa herkes için mi?

K5: Ama genelde heterolarda insanlar evlendikten çok kısa süre sonra bile eşi kilo aldığı zaman o eşi terk etmiyor. Ama geylikte sen biraz çirkinsen seni hemen terk ederler. Kesin yani bu yüzde yüz kanıtlanmış bu gördüğüm bir şey yani. Ben şimdi mesela birazcık fitliğimi kaybedeyim birazcık sağım solum eğilsin kırışsın beni en fazla 3 ay taşır, 3 ay sonra terk eder.

$[\cdots]$ 
K5: ... yani gey ilişkilerde yaşlı ve genç kavramı hetero ilişkilerdeki gibi değil. Şimdi mesela gey ilişkilerde ben ve partnerim gibi ilişkilerde bizi gördükleri zaman genelde bunu çok uygun görmez arada 20 yaş fark var. Hetero ilişkiler genelde birbirine yakın yaş oluyor. Geylerde bu tür birbirine yakın yaşlarda kurulan ilişkiler çok az. Çünkü geylerde olguncu ve çıtırcı tabirleri var. Bazı gençler belki de baba şiddeti veya babasızlıktan dolayı bir baba figürü ararlar, bir baba figürünü sevmeye ihtiyaç duyarlar ve onlardan daha yaşlı insanlarla beraber olurlar. Ne olur bunlar bunlar belli bir süre sonra baba gelir 70 yaşına çocuk gelir 50 yaşına. 50 yaş hala bir şey yapma yaşıdır ama 70 yaş değildir, o artık o baba sevgisini de artık tatmıștır yani gidermiştir. Bu sefer de döner, kendisi için diğer dürtüleri için bir şey arar. Ondan dolayı da 70 yaşındaki insan yalnız kalır. Yani yoksa bu çok basit bir şeydir. Heterolardaki gibi yakın yaş grubu olsaydı böyle olmazdı ama yakın yaş grubu diye kimse șey yapmıyor, çok azdır yakın yaş grubu (...)

\section{TARTIŞMA, SONUÇ VE ÖNERİLER}

Bu çalışmada, Türkiye'de orta yetişkinlik dönemindeki geylerin öznel iyi oluşlarına dair anlam inşaları ilk kez incelenmiş ve katılımcıların açıklamalarında "uzun süreli ve güvenli bir partner ilişkisi' öne çıkan söylemsel kaynaklardan (açıklayıcı repertuarlardan) biri olarak tespit edilmiştir. Daha önce de belirtildiği gibi, belirli bir konu hakkında konuşurken, söylemsel dağarcığımızda mevcut olan söylemsel kaynakları (belirli açıklama biçimleri, tarifler, metaforlar, vs.) o anki etkileşim bağlamına uygun biçimde çekip kullanırız, böylece söz konusu olguya dair açıklamalarımızı inşa ederiz (Wetherell ve Potter, 1988). Çalışmanın katılımcılarının da mutluluğa ve öznel iyi oluşa dair açıklamalarını inşa etmek üzere özellikle uzun süreli ve/veya güvenli bir romantik ilişkiye vurgu yaptıkları görülmüștür. Katılımcılar, duygusal derinliği olan, karşılıklı güven ve paylaşımı içeren, görece devamlılığı olan bir ilişkinin varlığını, mutlulukları ve/veya yaşam doyumları açısından belirleyici bir durum olarak ifade etmişlerdir. Öyle ki bazı katılımcılar partnerleri olmadığı için kendilerini açıkça "yalnız ve mutsuz" olarak nitelendirmişlerdir. Bu da literatürdeki araştırma sonuçlarıyla örtüşmektedir. Daha önce de belirtildiği gibi, eşcinsel bireylerin bir partnerle yaşlanmayı, yalnızlıkla baş etmek açısından önemli gördükleri ifade edilmektedir (Berger, 1982). Ayrıca Keyes ve Ryff (1999) ile Owen, Çelik ve Doğan'ın (2017) yaptıkları araștırmaların sonuçları da öznel iyi oluş ile romantik ilişkinin varlığı arasında pozitif ilişski olduğunu ortaya koymaktadır. Bu pozitif ilişkide, güvenli bir ilişki içinde bulunulan partnerin önemli bir sosyal destek kaynağı olmasının da oldukça etkisi vardır. Nitekim literatür kısmında belirtildiği gibi çeşitli çalışmalar öznel iyi oluş ile sosyal destek arasındaki ilişkiyi ortaya koymaktadır (ör. Toplu-Demirtaş ve ark., 2018). Homofobik önyargı ve ayrımcılık nedeniyle, eşcinsel bireylerin heteroseksüel akranlarına nazaran çok daha sınırlı 
sosyal destek kaynaklarına sahip oldukları göz önüne alındığında, güven duyulan bir partnerin varlığının önemi daha da anlaşılabilir hale gelmektedir. Bu noktada, mevcut araştırmada da katılımcıların mutlu ve doyumlu olup olmadıklarını öncelikle güvendikleri bir partnerin varlığı üzerinden anlamlandırmaya çalışmaları, sözü edilen sonuçlarla örtüşmektedir.

Diğer yandan görüşmelerde geyler arasında uzun süreli ve/ya güvenli bir ilişkinin zor olabileceği, hatta mümkün olamayacağına dair inançlar da sıklıkla dile getirilmiştir. Bu noktada, Billig ve arkadaşlarının (1988) ifadesiyle bir “ideolojik ikilem” söz konusudur. İdeolojik ikilemler, açıklamalarımızda kullandığımız çeşitli söylemlerin sosyal alandaki etkileşimini veya mücadelesini de gözler önüne serer. Böylece bir olguya dair ideolojik ikilemler, bu olguya ilişkin sosyal alandaki çatışmaları, çelişkileri ve uyuşmazlıkları görme imkânı sunar. Görüşmelerde, katılımcıların uzun süreli/güvenli bir ilişkiye yaptıkları vurguyla birlikte gey camiada bu tür ilişkilerin pek mümkün olmadığına inanmaları, bir sosyal etkileşim alanı olan gey cemaat içindeki ideolojik ikilemlerden birini ortaya koymaktadır.

Katılımcıların, uzun süreli/güvenli ilişkinin neden mümkün ol(a)madığına dair açıklamaları farklı nedenler içermektedir. Bu nedenlerden birinde sadakatin eskisi kadar önemli bir değer olarak görülmediği ifade edilmiştir. Katılımcılar bu ifadelerini gey camia içindeki kendi tanıklıklarına dayandırmışlar, kendilerinin ve etraflarındaki kişilerin hayatlarından örnekler vermişlerdir. Örneğin, "olguncu" ve "çıtırcı" kavramından bahseden K5, Alıntı-6'da sunulduğu üzere, geyler arasındaki ilişkilerde yaş farkının çok fazla olmasının gey camiada genelde rastlanan bir durum olduğunu, "belki de baba figürünün eksikliği nedeniyle" genç geylerin yaşı daha büyük kişilere yöneldiğini, genç olanın yaşı ilerleyince ve babaya yönelik duygu açlığını "olgun" partneriyle doyurunca gençlere yönelerek dürtüleri için arayışa girdiğini ve böylece yaşı daha büyük olan bireyin yalnız kalma ihtimalinin yüksek olduğunu ifade etmiştir. Bunu da orta yaş ve sonraki dönemde artık gençler tarafından beğenilmeme, tercih edilmeme ve yalnız kalma ile ilișkilendirmiștir.

Bu noktada, söz konusu ikilemin, gey camiadaki yaşlanma olgusuna yönelik olumsuz bakış açısı ile de ilişkili olduğunu söylemek mümkün görünmektedir. Katılımcıların çoğu, yaşları ilerledikçe -heteroseksüellerden farklı olarak- beğenilme ve partner olarak istenir olmaya dair inançlarının azaldığını ifade etmişlerdir. Katılımcılar sosyal, entelektüel ve kişisel özelliklerinden ziyade fiziki görünüşlerinin ve genç olmalarının beğenilmelerinde daha etkili olduğunu düşünmekte ve bu durumu da içinde bulundukları gey cemaatin "gerçeği" olarak tanımlamaktadırlar. $\mathrm{Bu}$ da kaçınılmaz olarak yaşlılığı, ilişki yaşama ihtimalini azaltması gerekçesiyle olumsuzlamayı beraberinde getirmektedir. Bu tür bir açıklama biçimi, FredriksenGoldsen ve Muraco'nun (2010) gey ve lezbiyenlerin yaşlandıkça kendilerini cinsel olarak çekici hissetmemeye başladıkları ve bununla bağlantılı olarak depresif duygularının arttığı yönündeki 
bulgularıyla örtüşmektedir. Dahası, söz konusu olumsuzlama, Williamson ve Hartley'in (1998) ayrımcılık nedeniyle kendini "kötü" ve "istenmeyen" algılama ile "bedenini mükemmelleştirerek" bunu aşmaya çalışma arasındaki olası bağlantıyı da akla getirmektedir. Bu noktada, gey camiada genç ve fit bir bedene sahip olmanın belirli düzeylerde idealleştirildiğini (ör. Martins, Tiggemann ve Kirkbride, 2007), bunun da genç olan ve olmayan geyler arasında bir tür hiyerarşiye yol açabildiğini söylemek mümkün görünmektedir. Suen'in (2017) 50 yaş ve üstü geylerle yaptığı çalışmanın sonuçları da benzer bir duruma işaret etmektedir. Suen'in (2017) analizi, 50 yaş ve üstü geylerin, genç geylerin bedenlerini idealleştirdiklerini, "genç" ve "yaşlanan" bedenleri kıyaslayarak genç bedeni "çekici", yaşlanan bedeni ise "çekici olmayan" şeklinde tarif ettiklerini ortaya koymaktadır.

Sonuç olarak, çalışmamızın katılımcısı olan orta yetişkinlik dönemindeki geylerin öznel olarak kendilerini iyi ve mutlu olarak tanımlamalarında bir yandan uzun süreli/güvenli bir partner ilişkisinin varlığını özellikle öne çıkardıkları, diğer yandan gerek yaşlandıkça beğenilmeyeceklerini düşünmelerinden gerekse gey camiada güvenli/uzun süreli ilişkilerin pek mümkün olmadığına inanmalarından dolayı ilişki olasılıklarını düşük gördükleri söylenebilir. Gey camiada geçmişe göre sadakatin azaldığı ve hatta artık olmadığına dair sıkça ifade edilen görüş, katılımcılar tarafından güvenli bir ilişki yaşamanın önünde duran ve kabullenilmiş bir "gerçeklik" olarak inşa edilmektedir. Hem güvenli ilişkiye ihtiyaç duymaları hem de bunu bulamayacaklarını düşünmeleri, katılımcıların kendilerini ilişkilerde pasif bir şekilde konumlandırdıklarına dair bir soru işareti yaratmaktadır. Katılımcılar, sadakatin artık olmadığını ifade ettikleri gey cemaatten bireyler olarak bir yandan bu durumdan şikâyet ederken, diğer yandan bunu mevcut bir gerçeklik olarak normalleştirmekte ve mesele karşısında kendilerini edilgen konuma yerleştirmiş olmaktadırlar. $\mathrm{Bu}$ da mutlu ve doyumlu bir yaşam açısından özellikle vurguladıkları uzun süreli/güvenli bir ilişki arayışlarına ket vurabilecek bir durum olarak düşünülebilir.

Bu araştırmanın sonuçları, Şubat-Mart 2019 döneminde, İstanbul'da ikâmet eden, kartopu yöntemiyle ulaşılmış olan 45-62 yaş arasındaki 10 geyle yapılan derinlemesine görüşmelerden elde edilen verilerle sınırlıdır. Çalışmanın İstanbul gibi büyük bir metropolde gerçekleştirilmiş olması ve katılımcı sayısının 10 kişi ile sınırlı kalmış olması, araştırmanın en önemli sınırlılığı olarak ifade edilebilir. Katılımeı grubunun kapsamını ve sayısını genişleterek yapılacak ileriki çalışmalar, mevcut çalışmanın sonuçlarını daha anlamlı hale getirecektir.

Diğer bir sınırlılık ise araştırmanın bütününde elde edilen 7 repertuarın hepsinin bu makalede bütüncül bir şekilde sunulamamış olmasıdır. Bu durum, makalede detaylı bir 
şekilde sunulan "uzun süreli ve güvenli ilişki”" repertuarının, görüşmelerden elde edilen diğer repertuarlarla nasıl bir ilişkisellik içinde olduğunu aktaramamış ve dolayısıyla katılımcıların anlam inşaların bütüncül bir şekilde sunamamış olmamızı beraberinde getirmiştir.

Belirtilen sınırlılıklardan hareketle, ileride yapılacak çalışmalara yönelik bir takım önerilerde bulunulabilir. Örneğin, bir yandan uzun süreli/güvenli ilişkiyi mutlulukla bağlantılandırıp diğer yandan bu tür bir güvenli ilişki ihtimalini düşük olasılıklı görme şeklinde karşımıza çıkan ideolojik ikilem, ilerde yapılacak çalışmalar için bir hareket noktası oluşturabilir. Farklı katılımcı gruplarla (örneğin, geç yetişkinlik dönemindeki geyler, farklı yaş dönemlerindeki lezbiyenler ve biseksüeller) ve farklı bağlamlarda yürütülecek çalışmaların daha geniş kapsamlı sonuçlara ulaşmak için faydalı olacağı söylenebilir. Son olarak, bireysel görüşmelere ek olarak odak grup görüşmesi, katılımcı gözlem, arşiv taraması, edebi eserler ve biyografiler gibi farklı veri kaynaklarının kullanılması da konuya dair daha kapsamlı bilgi edinme açısından faydalı olacaktır.

\section{KAYNAKÇA}

Arkonaç, S. A. (2014). Psikolojide Söz ve Anlam Analizi: Niteliksel Duruş. Ayrıntı.

Akturan, U., \& Baş, F. (2008). Nitel araştırma yöntemleri Nvivo 7.0 ile nitel veri analizi.Seçkin Yayıncilık.

Balcı, A. (2016). Sosyal bilimlerde araştırma yöntem, teknik ve ilkeler. Pegem Akademi.

Berger, M. R. (1982). The unseen minority: older gays and lesbians. National Assossiaciton of Social Workers, 27(3), 236-242. https://doi.org/10.1093/sw/27.3.236

Berghe, W. V., Dewaele, A., Cox, N., \& Vincke, J. (2010). Minority-specific determinants of mental well-being among lesbian, gay, and bisexual youth. Journal of Applied Social Psychology, 40(1), 153-166. https://doi.org/10.1111/j.1559-1816.2009.00567.x

Billig, M., Condor, S., Edwards, D., Gane, M., Middleton, D., \& Radley, A.R. (1988). Ideological thinking in everyday thinking. Sage.

Brennan-Ing, M., Karpiak, S. E., \& Seidel, L. (2011). Health and psychosocial needs of LGBT older adults. AIDS Community Research Initiative of America. https://www.centeronhalsted.org/SAGE.pdf

Burr, V. (2012). Sosyal inşacılık. (S. Arkonaç, Çev.). Nobel.

Cass, C. V. (1984). Homosexual identity formation: Testing a theoretical model. The Journal of Sex Research, 20(2), 143-167. https://doi.org/10.1080/00224498409551214

Choi, S. K., \& Meyer, I. H. (2016). LGBT Aging: A review of research findings, needs, and policy implications. The Williams Institute Report. https://williamsinstitute.law.ucla.edu/wpcontent/uploads/LGBT-Aging-Aug-2016.pdf

Diener, E., \& Ryan, K. (2009). Öznel iyi oluş: genel bir bakış. (N. Gencer, 2018, Çev.). Hitit Üniversitesi Sosyal Bilimler Enstitüsü Dergisi, 11, 2621-2638. https://doi.org/10.17218/hititsosbil.457382

Diener, E., Emmons, R. A., Larsen, R. J., \& Griffin, S. (1985). The satisfaction with life scale. Journal of Personality Assessment, 49, 71-75. https://doi.org/10.1207/s15327752jpa4901_13 
Dolan, P., Peasgood, T., \& White, M. (2008). Do we really know what makes us happy? A review of the economic literature on the factors associated with subjective well-being. Journal of Economic Psychology, 94-122. https://doi.org/10.1016/j.joep.2007.09.001

Fredriksen-Goldsen, K. I., Kim, H., Emlet, C. A., Muraco, A., Erosheva, E. A.,Hoy-Ellis,, C. P., Goldsen, J., \& Petry, H. (2010). The aging and health report. https://www.familleslgbt.org/1463149763/Fredriksen-Goldsen\%202011.pdf

Fredriksen-Goldsen, K. I., \& Muraco, A. (2010). Aging and sexual orientation: A 25-year review of the literature. National Institute of Health, 32(3), 372-413. https://doi.org/10.1177/0164027509360355

Güney, N., Kargı, E., \& Çorbacı Oruç, A. (2004). Üniversite öğrencilerinin eşcinsellik konusundaki görüşlerinin incelenmesi: Farklı Yüzleriyle Cinsellik. V. Ulusal Cinsellik ve Cinsel Tedaviler Kongresi, 24-26 Mayıs 2004, İstanbul.

Hyde, J. S., \& DeLamater, J. D. (2011). Understanding Human Sexuality. McGraw-Hill.

Kagan, J. (2003). Biology, context and developmental inquiry. Annual Review Psychology, 54, 123. https://doi.org/10.1146/annurev.psych.54.101601.145240

KAOS GL (2017). Eşcinsellikle İlgili Sıkça Sorulan Sorular. https://kaosgl.org/haber/escinsellikleilgili-sikca-sorulan-sorular

Kasapoğlu, F., \& Kış, A. (2016). Öznel iyi oluşun cinsiyet açısından incelenmesi: Bir meta-analiz çalışması. Mersin Üniversitesi Eğitim Fakültesi Dergisi, 12, 770-782.

Kemer, G., Toplu-Demirtaş, E., Pope, A.L., \& Ummak, E. (2017). Psychometric properties of the lesbian, gay, and bisexual identity scale - Turkish (LGBIS-TR). Journal of Homosexuality, 64(12), 1632-1649. https://doi.org/10.1080/00918369.2016.1249741

Keyes, C., \& Ryff, C. (1999). Psychological well-being in midlife. Life in Middle. 161-180.

Lachman, M. E. (2004). Development in midlife. Annual Review of Psychology, 55, 305-331. https://doi.org/10.1146/annurev.psych.55.090902.141521

Levinson, D. J. (1986). A conception of adult development. American Psychologist, 41(1), 3-13.

Li, Y., Johnson, B. D., \& Jenkins-Guarnieri, M. A. (2013). Sexual identity development and subjective well-being among Chinese lesbians. International Perspectives in Psychology: Research, Practice, Consultation, 2(4), 242-254. https://doi.org/10.1037/a0033752

Luhmann, M. (2017). The development of subjective well-being. Personality Devlopment Acrossthe Lifespan. http://dx.doi.org/10.1016/B978-0-12-804674-6.00013-2

Lyubomirsky, S., Sheldon, K. M., \& Schkade, D. (2005). Pursuing happiness: The architecture of sustainable change. Review of General Psychology, 9, 111-131. https://doi.org/10.1037/1089-2680.9.2.111

Martins, Y., Tiggemann, M., \& Kirkbride, A. (2007). Those speedos become them: The role of selfobjectification in gay and heterosexual men's body image. Personality and Social Psychology Bulletin, 33(5), 634-647.

Miller, P. H. (2017). Gelişim psikolojisi kuramları (Z. Gültekin, Çev.). Ankara: İmge Kitabevi.

Mroczek, D.K., \& Spiro, A. (2005). Change in life satisfaction during adulthood: Findings from theveterans affairsnormative aging study. Journalof Personality and Social Psychology, 88, 189-202.

Myers, D., \& Diener, E. (1995). Who is happy. American Psychological Society, 6, 1-19. https://doi.org/10.1111/j.1467-9280.1995.tb00298.x

Mohr, J. J., \& Kendra, M. S. (2011). Revision and extension of a multidimensional measure of sexual minority identity: the Lesbian, Gay, and Bisexual Identity Scale. Journal of Counseling Psychology, 58(2), 234-245. https://doi.org/10.1037/10022858 
Owen, F. K., Çelik, N. D., \& Doğan, T. (2017). Yetişkinlerde iyilik hali. Uluslararası Sosyal Araștırmalar Dergisi, 53, 600-611.

Ryff, C. D. (1989). Happiness is everything, or is it? Explorations on the meaning of psychological well-being. Journal of Personality and Social Psychology, 57(6), 1069-1081.

Ryff, C. D. (1995). Psychological well-being in adult life. Current Directions in Psychological Science, 99-104. https://doi.org/10.1111/1467-8721.ep10772395

Safren, S. A., Hollander, G., Hart, T. A., \& Heimberg, R. G. (2001). Cognitive-behavioral therapy with lesbian, gay, and bisexual youth. Cognitive and Behavioral Practice, 8(3), 215-223. https://doi.org/10.1016/S1077-7229(01)80056-0

Smith, J. A. (1995). Semi-structured interviewing and qualitative analysis. J. A. Smith, R. Harre ve L. V. Langenhove (Ed.), Rethinking methods in psychology içinde (s. 9-26). Sage.

Specht, J. (2017). Personality development in adulthood and old age. J. Specht (Ed.), Personality development across the lifespan içinde (s. 53-67). Elsevier Academic Press.

Suen, Y.T. (2017). Older single gay men's body talk: Resisting and rigidifying the aging discourse in the gay community. Journal of Homosexuality, 64(3), 397-414. https://doi.org/10.1080/00918369.2016.1191233

TODAP (2017). Psikologlar için LGBTílerle çalışma kılavuzu. TODAP.

Toplu-Demirtaş, E., Kemer, G., Pope, A.L., \& Moe, J.L. (2018). Self-compassion matters: The relationships between perceived social support, self-compassion, and subjective wellbeing among LGB individuals in Turkey. Journal of Counseling Psychology. 65(3), 372382.

Wetherell, M., \& Potter, J. (1988). Discourse analysis and the identification of interpretative repertoires. C. Antaki (Ed.), Analyzing Everyday Explanation: A Casebook of Methods içinde (s.168-183). Sage.

Williamson, I., \& Hartley, P. (1998). British research into the increased vulnerability of young gay men to eating disturbance and body dissatisfaction. European Eating Disorders Review, 6(3), 160-170. https://doi.org/10.1002/(SICI)1099-0968(199809)6:3<160::AIDERV252>3.0.CO;2-H

Yalçın, İ. (2014). İyi oluş ve sosyal destek arasındaki ilişkiler: Türkiye'de yapılmış çalışmaların meta analizi. Türk Psikiyatri Dergisi, 25. https://doi.org/10.5080/u7769

Yıldırım, A., \& Şimşek, H. (2013). Sosyal bilimlerde nitel araştırma yöntemleri. Seçkin Yayınevi.

Zastrow, C., \& Kirst-Ashman, K. (2015). Insan davranışı ve sosyal çevre II - Yetişsinlik yaşlılık (S. Türközü, ve B. Alparslan, Çev.). Nika Yayınevi. 


\section{EXTENDED ABSTRACT}

\section{Introduction}

The interest in "happiness" and "the well-being" of the individual, which are among the main areas of study of psychology, dates back to the ancient Greek philosophers' question of "how can human be happy" and earlier. Although subjective well-being has been an critical research theme in the last two decades, depending on heteronormatif approach, these studies were mostly conducted with heterosexual male and female participants were observed. Considering that large communities have subgroups with differences, it should be noted that these differences will also have different effects on subjective well-being.

In this study, the discourses of gays in middle adulthood about subjective well-being, a concept that includes happiness, are discussed. According to results of Özkan's (2019) study, the "interpretative repertoires" that middle aged gay man living in Istanbul use to explain their subjective well-being have been examined. In this article, "long-term and safe partner relationship", one of the repertoires of the study, was analyzed and discussed in detail.

\section{Method}

"Discourse analysis", a qualitative research model, was used in this study. On average, one hour of face-to-face and semi-structured interviews were conducted with each participant. Interviews were recorded audio and then deciphered on computer. The data obtained were examined by Discourse Analysis and "interpretative repertoires" were reached which were the source of the participants' explanations.

The study included 10 gay participants between the ages of 45 and 62, living in Istanbul and having different educational levels. The participants were reached by snowball method. In the beginning of the interviews, participants were informed about the research, it was stated that the interview would be recorded with a voice recorder, and approval was obtained from the participants that they had voluntarily participated in the study.

As part of the research, a pilot interview was conducted primarily in preparation. Since the concept of "subjective well-being" in the pilot interview is far removed from those who are not professionals in the field of psychology, in question form this concept is substituted with "happiness" and "life satisfaction". In the pilot interview, as it was seen that the interview can be deepened by diversifying the questions, the relationships that are parameters of subjective wellbeing, personality structure, belief, education level, income level and the relationship of health with the feeling of having a happy and satisfied life were asked.

\section{Results}


This analysis, which includes the first part of Özkan's (2019) study, examined "longterm/safe partner relationship" from repertoire sources to descriptions of happiness and life satisfaction of middle aged gays.

In interviews, participants stated that a long-term secure partner relationship is important in making them feel good and happy and also satisfied in their lives. The lack of a long-term secure partner relationship has been described as a cause of unhappiness, and the need to feel belonging to a safe relationship has been highlighted. However, when we look at the participants' statements, it is seen that they have observations and beliefs that a long-term partner relationship in gay community is unlikely, and that they have explained the perception of loneliness brought about by aging.

\section{Discussion \& Conclusion}

It can be said that the participants of the study, who are in their middle adulthood, subjectively describe themselves as good and happy in the existence of a long-term/safe partner relationship. So much that some participants openly described themselves as "lonely and unhappy" because they did not have a partner. This is in line with the research results in the literature. In addition, on one hand, they will not be liked as they get older as a partner candidate and on the other hand, they view their safe relationship possibilities low in the gay community, the often expressed view that loyalty has diminished and even no longer exists is constructed as an accepted "reality" that stands in the way of having a safe relationship. Both the need for safe relationship and the fact that they don't think they can find it raises a question mark that participants are passively positioning themselves in the relationship. The interviewees, as individuals from the gay community where they express no more loyalty, both complain about it and position themselves passive in the face of it and seem to accept it as normal.

On the one hand, the dilemma of linking a long-term/safe relationship to happiness and on the other hand, the possibility of such a safe relationship may be considered as a low probability, and in addition, it can be said that studies carried out with different participating groups will be useful for reaching more comprehensive results. 